Western North American Naturalist 70(2), (C) 2010, pp. 198-207

\title{
THE MONTANE BEE FAUNA OF NORTH CENTRAL WASHINGTON, USA, WITH FLORAL ASSOCIATIONS
}

\author{
Joseph S. Wilson ${ }^{1}$, Lindsey E. Wilson² ${ }^{2}$ Larry D. Loftis ${ }^{3}$, and Terry Griswold ${ }^{4}$
}

\begin{abstract}
AвSTRACT-The mountains of north central Washington contain a variety of habitat types, from shrubsteppe to high alpine meadows. While native bee surveys of some surrounding areas like the Columbia Basin are fairly complete, little work has been done in the mountains of north central Washington to document the diversity of bees found therein. We conducted a survey of native bees in the Tonasket Ranger District of the Okanogan-Wenatchee National Forest during summer 2004. Collections yielded a diverse bee fauna (140 species in 24 genera) visiting diverse floral elements (57 plant species in 18 families). These preliminary data suggest that a rich bee fauna exists in the Okanogan Basin and surrounding mountains.
\end{abstract}

Key words: pollinators, bees, Apoidea, Pacific Northwest, biodiversity.

Increased awareness of the important role native bees play as pollinators has led to recent collaborative efforts between researchers and land managers to document bee faunas in North America (Griswold et al. 1998, Messinger and Griswold 2002, Gardner and Ascher 2006, Giles and Ascher 2006, Messinger 2006, Brosi et al. 2007, Wilson et al. 2008). Yet the bee fauna of many ecosystems remains largely unknown. Furthermore, the results of many studies documenting native bee faunas are largely inaccessible, as they are often submitted solely as reports to the funding agency. While these reports are not generally off-limits to the public, researchers must first be aware that a report exists and then find the correct contact person before they can access the information.

The apparent lack of published work documenting native bee faunas may be due, in part, to the notion that a study resulting in little more than a species list is not appropriate for peerreviewed journals. We would argue, however, that species lists, particularly for bees, are invaluable for many reasons. Studies show that native bees are important components of agricultural systems; however, specific bee species need certain requirements in order to be effective pollinators (Kremen et al. 2004, Ratti et al. 2008). Native bees are increasingly being used as pollinators for several agricultural crops (e.g., rapeseed and blueberries), so understanding the resource needs and floral visitation preferences of native bees can be key to developing sustainable agricultural plans (Wood 1979, Morandin and Winston 2006).

Besides benefiting agricultural crops, native bees perform an essential function in the maintenance of natural ecosystems through their role as pollinators. Because of the vital ecosystem service bees provide, land managers have been increasingly interested in documenting the native bee faunas in their lands. For example, in the past 10 years, Zion National Park, Yosemite National Park, the Grand Staircase National Monument, Pinnacles National Monument, Dugway Proving Grounds, and Ash Meadows National Wildlife Refuge have invested in efforts to document their bee faunas. However, it is difficult for land managers to assess the quality and distinctiveness of their bee faunas without other published reports of species richness and abundance. Additionally, understanding the diversity and floral preferences of native bees can be important in efforts to protect rare or endangered plants (e.g., Pavlik et al. 1993).

Perhaps the most important reason to document native bee faunas is the rapid decline worldwide in native pollinators (e.g., Kerns and Inouye 1997, Biesmeijer et al. 2006). Specialist bees are more vulnerable to decline than are generalist bees (Biesmeijer et al. 2006). Thus it is important to document the distributions, habitat, and floral preferences of specialist bees, in addition to documenting bee species.

\footnotetext{
${ }^{1}$ Department of Biology, Utah State University, 5305 Old Main Hill, Logan, UT 84322-5305. E-mail: joseph.wilson@usu.edı

2335 East 700 North, Logan, UT 84321

${ }^{3}$ Tonasket Ranger District, 1 West Winesap, Tonasket, WA 98855.

${ }^{4}$ USDA ARS Bee Biology and Systematics Laboratory, 5310 Old Main Hill, Logan, UT 84322-5310.
} 


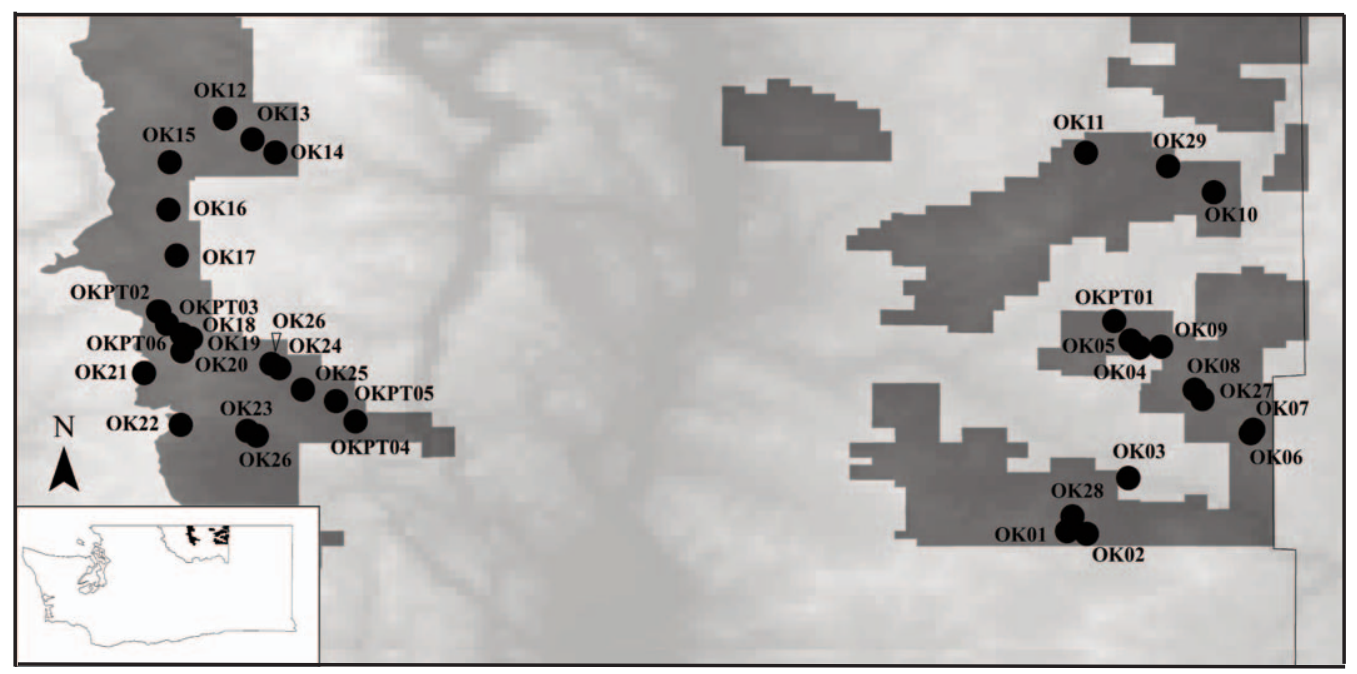

Fig. 1. Map of the Tonasket Ranger District of the Okanogan National Forest with collection locations and ranger district boundaries marked.

Although studies have documented bee faunas in several western desert regions (e.g., Messinger and Griswold 2002, Messinger 2006, Wilson et al. 2008), little work has been done to record the bee fauna of the montane region of north central Washington. Situated in northern Washington between the Rocky Mountains and Cascade ranges, this montane region contains diverse habitats-from shrubsteppe lowlands, to midelevation forests, to alpine lakes and meadows (Lasmanis 1991, Scudder 1992 , Ricketts et al. 1999).

The bees of much of the Columbia Basin are well documented (Tepedino and Griswold 1995, Niwa et al. 2001), yet only a handful of records exist from the mountains of north central Washington. One general insect survey reported 78 bee species from the Mount Kobau area of the Okanogan Basin in southern British Columbia, Canada (Blades and Maier 1996). This study is incomplete regarding bee richness, as the majority of bees were only identified to the genus level and designated as morphospecies. Furthermore, the area covered by the study was relatively small.

Reported here are the findings of a study done during the summer of 2004 in the Tonasket Ranger District of the Okanogan-Wenatchee National Forest, Okanogan County, in northern Washington. The goal of this study was to provide a preliminary estimate of bee diversity across the Tonasket Ranger District. We focused on areas of concern, such as areas targeted for conservation and areas containing high floral abundance. While comparisons of bee faunas across regions are worthwhile and interesting, due to the preliminary nature of this study, we do not attempt to make such comparisons.

\section{Methods}

In order to collect from the spring as well as the summer bee fauna, 2 surveys were conducted in 2004: one from 28 June to 9 July and another from 9 August to 14 August. Efforts have been made to standardize collection methods among bee researchers (LeBuhn et al. 2003); however, our goal was to gain a preliminary understanding of bee diversity, so our methods were designed to maximize the number of species collected. Two trained collectors made collections in 35 locations across the ranger district (Fig. 1). Each of the 35 sites was collected in late June as well as early August. The majority of collection sites were in mountainous regions ranging in elevation from $785 \mathrm{~m}$ to $2502 \mathrm{~m}$ (Table 1). Collection events consisted of 2 researchers sampling from all flowering plants in a given area (no more than 1 ha in size) for 30 minutes. Collecting was primarily done by net (29 locations). When logistically possible, net collecting was augmented by use of pan traps near net collections. Pan-trap collections consisted of 30 colored plastic bowls (10 fluorescent 
TABLE 1. Site descriptions for all 35 collection locations. Location names correspond to those found in Figure 1. Location names beginning with OKPT represent locations where pan traps were deployed. Locations from OK01 through OK29 were sampled using nets only.

\begin{tabular}{|c|c|c|c|c|}
\hline Location name & Location description & Elevation $(\mathrm{m})$ & Latitude & Longitude \\
\hline$\overline{\mathrm{OK} 01}$ & 1.5 mi E Bailey Mountain & 1260 & 48.49443423 & -119.0715511 \\
\hline OK02 & Cox Meadow & 1117 & 48.49199923 & -119.0523257 \\
\hline OK03 & 1.5 mi NNE Lyman Lake & 785 & 48.54629216 & -119.011878 \\
\hline OK04 & Turner Lake & 1273 & 48.67374532 & -119.0008927 \\
\hline OK05 & 1 mi NW Turner Lake & 1329 & 48.68069163 & -119.0096187 \\
\hline OK06 & $0.3 \mathrm{mi}$ E Cornell Butte & 1526 & 48.5937285 & -118.8897009 \\
\hline OK07 & $0.4 \mathrm{mi}$ S Cornell Butte & 1449 & 48.59034901 & -118.892233 \\
\hline OK08 & $0.5 \mathrm{mi}$ W Corner Butte & 1349 & 48.63288002 & -118.9470178 \\
\hline OK09 & 2 mi W Corner Butte & 1342 & 48.67475761 & -118.9798357 \\
\hline OK10 & Virginia Lilly Trailhead & 1262 & 48.82551614 & -118.9284066 \\
\hline OK11 & $1 \mathrm{mi} \mathrm{N}$ Lost Lake & 1115 & 48.86401249 & -119.0532095 \\
\hline OK12 & $0.3 \mathrm{mi} \mathrm{S}$ Hodges Horse Pasture & 2045 & 48.89751079 & -119.8921573 \\
\hline OK13 & 3 mi SE Hodges Horse Pasture & 1670 & 48.8768845 & -119.8657726 \\
\hline OK14 & 2.4 mi W Duncan Ridge & 1465 & 48.8643688 & -119.8433467 \\
\hline OK15 & Long Swamp & 1660 & 48.85481852 & -119.9462933 \\
\hline OK16 & 1.5 mi SSW Corral Butte & 1796 & 48.80844473 & -119.9477278 \\
\hline OK17 & $0.4 \mathrm{mi}$ SW Thunder Mountain & 1966 & 48.7637014 & -119.9396076 \\
\hline OK18 & Tiffany Lake & 2010 & 48.68658891 & -119.9344606 \\
\hline OK19 & $0.8 \mathrm{mi}$ W Tiffany Lake & 2221 & 48.68286902 & -119.9254527 \\
\hline OK20 & Tiffany Mountain & 2502 & 48.66998316 & -119.9339573 \\
\hline OK21 & Roger Lake & 1802 & 48.64905108 & -119.9711436 \\
\hline OK22 & 1 mi E Baldy Pass & 1884 & 48.59832214 & -119.935499 \\
\hline OK23 & 1.5 mi SSW Muckamuck Hill & 1400 & 48.59263243 & -119.8705777 \\
\hline OK24 & Salmon Meadows & 1351 & 48.65355557 & -119.8394758 \\
\hline OK25 & $1.5 \mathrm{mi}$ NNE Sophys Meadows & 1114 & 48.63272623 & -119.8164779 \\
\hline OK26 & 2 mi NW Salmon Meadows & 1315 & 48.58774896 & -119.8614852 \\
\hline OK27 & 0.8 mi S Corner Butte & 1290 & 48.6234261 & -118.9394614 \\
\hline OK28 & $1.3 \mathrm{mi}$ NNW Cox Meadow & 1349 & 48.50910242 & -119.0663945 \\
\hline OK29 & Beaver Lake & 825 & 48.85079554 & -118.9730419 \\
\hline OKPT01 & $1.3 \mathrm{mi}$ W Suttons Meadow & 1245 & 48.69976692 & -119.0253969 \\
\hline ОКРТ02 & Quarry at Three Buttes & 2096 & 48.7089972 & -119.956375 \\
\hline OKРT03 & Parachute Meadow & 2086 & 48.70896746 & -119.9575289 \\
\hline OKРT04 & 1 mi E Muckamuck Hill & 1213 & 48.60161159 & -119.7651077 \\
\hline OKPT05 & $0.7 \mathrm{mi}$ SW Middle Mountain & 1183 & 48.62161169 & -119.7841423 \\
\hline OKРT06 & 1 mi NNW Tiffany Lake & 1990 & 48.69681491 & -119.9490144 \\
\hline
\end{tabular}

yellow, 10 fluorescent blue, and 10 white) filled with soapy water and set at 1-m intervals along a single transect line. Pan traps were deployed at a total of 6 sites (Table 1). All collecting localities were georeferenced with a Garmin GPS unit.

Bee identifications were made by Terry Griswold, Harold Ikerd, Olivia Messinger, and Joseph Wilson using the U.S. National Pollinating Insects Collection, Logan, Utah. Where possible, specimens were identified to species. Where species could not be assigned to a published name, as in some unrevised genera, they were given alphanumeric names to distinguish them as morphospecies (e.g., Andrena sp. 1). Some difficult groups of specimens, often males, were labeled "spp.," denoting that the group was composed of multiple species that could not reliably be separated or associated with one of the morphospecies. All bees were labeled with GPS coordinates for the site at which they were collected, along with a location reference, the flower on which they were collected, the date, and the collector's name. All specimens are deposited in the U.S. National Pollinating Insects Collection.

Floral identifications were made by Larry Loftis. The plant specimens were identified using 3 floras, Douglas et al. (1998-2001), Hitchcock et al. (1955-1969), and Hitchcock and Cronquist (1973).

\section{REsults AND Discussion}

A total of 1975 bees representing 140 species in 24 genera (Appendix 1) were collected from the Tonasket Ranger District of the Okanogan-Wenatchee National Forest. This collection demonstrates that the mountains of north central Washington support significantly 
higher bee diversities than were previously known (Blades and Maier 1996). The increased diversity found in this study compared to the earlier work is likely not only a product of the broad range of environments that were sampled but also a result of collecting techniques focused on bees.

Bees were collected from 57 plant species in 18 families (Appendix 2). Asteraceae predominated with $32 \%$ of the plant species visited and with 4 of the 7 most visited plants: Erigeron speciosus var. speciosus (42 bee species), Achillea millefolium and Taraxacum officinale (24 species each), and Anaphalis margaritacea (23 species). Other well-visited plants included Phacelia leptosepala (Hydrophyllaceae, 24 bee species), Potentilla gracilis (Rosaceae, 23 species), and Penstemon washingtonensis (Scrophulariaceae, 22 species).

This survey revealed a surprisingly high diversity in 4 bee genera: Osmia (26 species), Andrena (17 species), Bombus (bumblebees, 14 species), and Hylaeus (7 species, including 2 possibly new species). In addition to the 2 potentially new species of Hylaeus, Dufourea maura represents a northwestern range extension for the species, and Dufourea trochantera is a new state record.

Many bees are known to be floral specialists, visiting a single group of closely related plants. Of the bees collected in the Tonasket Ranger District of the Okanogan-Wenatchee National Forest, several are known specialists (Hurd 1979, T. Griswold unpublished data). Asteraceae supports 17 specialist species collected in the 2004 study (Andrena evoluta, Ashmeadiella cubiceps, Colletes fulgidus, Dianthidium heterulkei, D. subparvum, D. ulkei, Heriades cressoni, Megachile fidelis, M. perihirta, Osmia californica, O. coloradensis, O. marginipennis, O. montana, and O. subaustralis). Phacelia supports 6 specialist bees (Colletes consors, Dufourea trochantera, Anthidium mormonum, A. tenuiflorae, Atoposmia copelandica, and Chelostoma minutum). Many other bees collected in this study are known specialists: Atoposmia elongata, Osmia brevis, and O. penstemonis, on Penstemon; Megachile melanophaea, Osmia albolateralis, and O. odontogaster on Fabaceae; Colletes consors on Potentilla; Dufourea maura on Campanula; Osmia longula on Astragalus; O. pikei on Ribes; and O. sculleni on Hackelia.

Because many bee species have short, highly seasonal lives and exhibit patchy distributions on the landscape, this study must be viewed as preliminary. This study presents a partial baseline of comparison for future faunistic studies, and we expect that numerous additional species will be detected with further sampling at other stages in the flowering phenology, at different sites, and on additional floral elements.

\section{ACKNOWLEDGMENTS}

We thank Harold Ikerd and Olivia Messinger for help in identifying bees; Jason Gibbs navigated the morass of Lasioglossum (Dialictus), for which we are very grateful. We are also indebted to the Tonasket Ranger District Office for supplying us with the materials and funding that made this project possible.

\section{Literature Cited}

Biesmeijer, J.C., S.P.M. Roberts, M. Reemer, R. Ohlemuller, M. Edwards, T. Peeters, A.P. Schaffers, S.G. Potts, R. Kleukers, C.D. Tomas, et AL. 2006. Parallel declines in pollinators and insect-pollinated plants in Britain and The Netherlands. Science 313: 351-354.

Blades, D.C.A., AND C.W. MaIER. 1996. A survey of grassland and montane arthropods collected in the southern Okanagan region of British Columbia. Journal of the Entomological Society of British Columbia 93:49-73.

Brosi, B.J., G.C. Daily, And P.R. EhrLich. 2007. Bee community shifts with landscape context in a tropical countryside. Ecological Applications 17:418-430.

Douglas, G.W., D. Meidinger, and J. Pojar. 1998-2001. Illustrated flora of British Columbia. Volumes 1-7. B.C. Ministry of Environment, Lands \& Parks, and B.C. Ministry of Forests, Victoria, British Columbia, Canada.

GardnER, K.E., AND J.S. Ascher. 2006. Notes on the native bee pollinators in New York apple orchards. Journal of the New York Entomological Society 114:86-91.

Giles, V., AND J.S. Ascher. 2006. A survey of the bees of the Black Rock Forest Preserve, New York (Hymenoptera: Apoidea). Journal of Hymenoptera Research 15:208-231.

Griswold, T.L., F.D. Parker, and V.J. Tepedino. 1998. The bees of the San Rafael Desert: implications for the bee fauna of the Grand Staircase-Escalante National Monument. Pages 175-186 in L.M. Hill, editor, Learning from the land: Grand StaircaseEscalante National Monument Science Symposium Proceedings, Nov. 4-5, 1997, Southern Utah University. U.S. Department of the Interior, Bureau of Land Management. Paragon Press, Salt Lake City, UT.

HitchCock, C.L., AND A. Cronquist. 1973. Flora of the Pacific Northwest. University of Washington Press, Seattle, WA.

Hitchcock, C.L., A. Cronquist, M. Ownbey, and J.W. Thompson. 1955-1969. Vascular Plants of the Pacific Northwest, Parts 1-5. University of Washington Press, Seattle, WA. 
HuRD, P.D., JR. 1979. Superfamily Apoidea. Pages 17412209 in K.V. Krombein, editor, Catalog of Hymenoptera in America north of Mexico. Volume 2. Smithsonian Institution Press, Washington DC.

Kerns, C.A., AND D.W. InOuYE. 1997. Pollinators, flowering plants, and conservation biology. BioScience 47 : 297-307.

Kremen, C., N.M. Williams, R.L. BugG, J.P. Fay, and R.W. Thorp. 2004. The area requirements of an ecosystem service: crop pollination by native bee communities in California. Ecology Letters 7:1109-1119.

LaSManis, R. 1991. The geology of Washington. Rocks and Minerals 66:262-277.

LeBuhn, G., T. Griswold, R. Minckley, S. Droege, T. Roulston, J. Cane, F. Parker, S. Buchmann, V. Tepedino, N. Williams, C. Kremen, and O. MesSINGER. 2003. A standardized method of monitoring bee populations - the bee inventory (BI) plot. [Cited September 2009]. Available from: http://online .sfsu.edu/ beeplot/.

Messinger, O., AND T.L. Griswold. 2002. A pinnacle of bees. Fremontia 30:32-40.

Messinger, O.J. 2006. A survey of the bees of Grand Staircase-Escalante National Monument, southern Utah: incidence, abundance, and community dynamics. Master's thesis, Utah State University, Logan, UT.

Morandin, L.A., And M.L. Winston. 2006. Pollinators provide economic incentive to preserve natural land in agroecosystems. Agriculture, Ecosystems and Enviroment 116:289-292.

Niwa, C.G., R.E. Sandquist, R. Crawford, T.J. Frest, T. Griswold, P. Hammond, E. Ingham, S. James, E.J. JOHANNES, J. JOHNSON, ET AL. 2001. Invertebrates of the Columbia River Basin Assessment Area. General Technical Report PNW-GTR-512, USDA Forest Service, Pacific Northwest Research Station, Portland, OR.

Appendix 1. List of bee species collected in the Okanogan region of north central Washington with abundances.

\begin{tabular}{lr}
\hline Family and species & $n$ \\
\hline ANDRENIDAE & \\
Andrena astragali & 1 \\
Andrena ceanothifloris cretata & 1 \\
Andrena columbiana & 1 \\
Andrena evoluta & 19 \\
Andrena knuthiana & 1 \\
Andrena miranda & 2 \\
Andrena nivalis & 1 \\
Andrena prunorum prunorum & 2 \\
Andrena quintiliformis & 3 \\
Andrena ribblei & 13 \\
Andrena rufosignata & 9 \\
Andrena salifloris & 2 \\
Andrena scutellinitens & 6
\end{tabular}

Pavlik, B.M., N. Ferguson, and M. Nelson. 1993. Assessing limitations on the growth of endangered plant populations, II. Seed production and seed bank dynamics of Erysimum capitatum ssp. angustatum and Oenothera deltoides ssp. howellii. Biological Conservation 65:267-278.

Ratti, C.M., H.A. Higo, T.L. Griswold, and M.L. WinSTON. 2008. Bumble bees influence berry size in commercial Vaccinium spp. cultivation in British Columbia. Canadian Entomologist 140:348-363.

Ricketts T.H., K. Carney, R.A. Abell, S. Walters, E. Dinerstein, D.M. Olson, C.J. Loucks, W. Eichbaum, D. DellaSalla, K. KaVanagh, ET al. 1999. Terrestrial ecoregions of North America: a conservation assessment. Island Press, Washington DC.

SCUDDER, G.G.E. 1992. Threatened and endangered invertebrates of the south Okanagan. Pages 47-57 in S. Rautio and B.C. Federation, editors, Community action for endangered species. Naturalist \& Northwest Wildlife Preservation Society, Vancouver, British Columbia, Canada.

Tepedino, V.J., and T.L. Griswold. 1995. The bees of the Columbia Basin. Final report, USDA Forest Service, Portland, OR. 212 pp.

Wilson, J.S., T. GRiswold, and O. Messinger. 2008. Sampling bee communities (Hymenoptera: Apiformes) in a desert landscape: are pan traps sufficient? Journal of the Kansas Entomological Society 81:288-300.

Wood, G.W. 1979. Recuperation of naïve bee populations in blueberry fields exposed to drift of fenitrothin from forest spray operations in New Brunswick. Journal of Economic Entomology 72:36-39.

Received 2 October 2009 Accepted 26 January 2010
Appendix 1. Continued.

\begin{tabular}{lr}
\hline Family and species & $n$ \\
\hline Andrena sp. 13 & 1 \\
Andrena sp. 5 & 1 \\
Andrena topazana & 5 \\
Andrena vicinoides & 2 \\
APIDAE & \\
Anthophora urbana & 1 \\
Anthophora ursina & 2 \\
Bombus appositus & 5 \\
Bombus bifarius & 176 \\
Bombus californicus & 2 \\
Bombus centralis & 20 \\
Bombus fernaldae & 3 \\
Bombus fervidus & 5 \\
Bombus flavifrons & 29 \\
Bombus insularis & 53 \\
Bombus melanopygus & 28
\end{tabular}


APPENDIX 1. Continued.

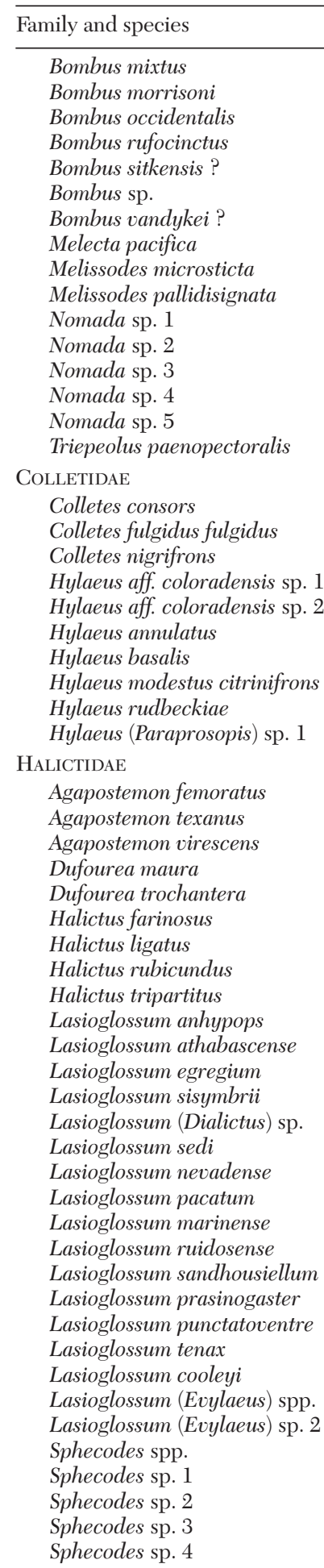

Appendix 1. Continued.

\begin{tabular}{rc}
\hline Family and species & $n$ \\
\hline Sphecodes sp. 5 & 8 \\
Sphecodes sp. 6 & 1
\end{tabular}

MEGACHILDAE

Anthidium mormonum 4

Anthidium tenuiflorae 5

Ashmeadiella cactorum $\quad 2$

Ashmeadiella cubiceps $\quad 2$

Atoposmia copelandica 1

Atoposmia elongata 3

Chelostoma minutum 2

Coelioxys moesta 2

Coelioxys sodalis $\quad 1$

Dianthidium heterulkei 1

Dianthidium subparvum 4

Dianthidium ulkei 1

Heriades cressoni 1

Hoplitis albifrons argentifrons $\quad 56$

Hoplitis fulgida fulgida 40

Hoplitis grinnelli 1

Hoplitis producta

Hoplitis robusta

Megachile centuncularis 1

Megachile fidelis

Megachile frigida 1

Megachile gemula 4

Megachile melanophaea 13

Megachile montivaga 1

Megachile perihirta 3

Megachile pugnata $\quad 7$

Megachile relativa $\quad 22$

Osmia albolateralis $\quad 8$

Osmia atrocyanea 2

Osmia bella? 1

Osmia brevis $\quad 12$

Osmia bucephala 2

Osmia californica 4

Osmia coloradensis $\quad 53$

Osmia exigua 1

Osmia juxta 24

Osmia longula 3

Osmia marginipennis 1

Osmia montana montana 13

Osmia nigriventris $\quad 2$

Osmia odontogaster 9

Osmia paradisica $\quad 88$

Osmia penstemonis 18

Osmia pikei 1

Osmia proxima 1

Osmia pusilla

Osmia sculleni 1

Osmia (Melanosmia) sp. $1 \quad 2$

$\begin{array}{lr}\text { Osmia (Melanosmia) sp. } 2 & 3 \\ \text { Osmia subaustralis } & 22\end{array}$

$\begin{array}{lr}\text { Osmia subaustralis } & 22 \\ \text { Osmia tanneri } & 7\end{array}$

Osmia trevoris

Osmia tristella 68

Stelis montana $\quad 4$

Stelis subcaerulea $\quad 1$

Stelis subemarginata 2 
APpendix 2. List of bee-visited flowers with bees collected from them $(n=$ number of individuals).

\begin{tabular}{|c|c|}
\hline Plant family / Flower binomial / Bee binomial & $n$ \\
\hline \multicolumn{2}{|l|}{ ASTERACEAE } \\
\hline \multicolumn{2}{|l|}{ Achillea millefolium (24 spp.) } \\
\hline Andrena scutellinitens & 1 \\
\hline Andrena topazana & 1 \\
\hline Bombus bifarius & 5 \\
\hline Bombus insularis & 1 \\
\hline Bombus melanopygus & 1 \\
\hline Bombus mixtus & 1 \\
\hline Colletes fulgidus & 3 \\
\hline Colletes nigrifrons & 1 \\
\hline Dufourea maura & 1 \\
\hline Halictus farinosus & 14 \\
\hline Halictus rubicundus & 1 \\
\hline Hoplitis fulgida & 1 \\
\hline Hoplitis producta & 1 \\
\hline Hylaeus aff. coloradensis sp. 1 & 3 \\
\hline Hylaeus aff. coloradensis sp. 2 & 1 \\
\hline Lasioglossum anhypops & 1 \\
\hline Lasioglossum sandhousiellum & 5 \\
\hline Lasioglossum tenax & 3 \\
\hline Megachile perihirta & 1 \\
\hline Megachile relativa & 1 \\
\hline Melissodes pallidisignata & 1 \\
\hline Nomada sp. 5 & 1 \\
\hline Osmia coloradensis & 5 \\
\hline Sphecodes sp. & 1 \\
\hline \multicolumn{2}{|l|}{ Agoseris glauca var. dasycephala (10 spp.) } \\
\hline Bombus bifarius & 3 \\
\hline Bombus insularis & 1 \\
\hline Bombus sp. & 1 \\
\hline Coelioxys sodalis & 1 \\
\hline Halictus farinosus & 1 \\
\hline Hylaeus annulatus & 1 \\
\hline Lasioglossum (Evylaeus) sp. 2 & 2 \\
\hline Osmia brevis & 1 \\
\hline Osmia coloradensis & 1 \\
\hline Osmia tristella & 1 \\
\hline \multicolumn{2}{|l|}{ Anaphalis margaritacea (23 spp.) } \\
\hline Andrena prunorum & 1 \\
\hline Andrena columbiana & 1 \\
\hline Andrena scutellinitens & 1 \\
\hline Bombus bifarius & 2 \\
\hline Bombus insularis & 3 \\
\hline Bombus melanopygus & 1 \\
\hline Colletes fulgidus & 1 \\
\hline Halictus farinosus & 2 \\
\hline Halictus ligatus & 1 \\
\hline Hylaeus aff. coloradensis sp. 1 & 6 \\
\hline Hylaeus aff. coloradensis sp. 2 & 6 \\
\hline Hylaeus annulatus & \\
\hline Hylaeus modestus & 1 \\
\hline Lasioglossum anhypops & 1 \\
\hline Lasioglossum (Evylaeus) spp. & 3 \\
\hline Lasioglossum (Evylaeus) sp. 2 & 2 \\
\hline Melissodes microsticta & 1 \\
\hline Osmia paradisica & 1 \\
\hline Osmia pusilla & 1 \\
\hline Sphecodes sp. & 2 \\
\hline Sphecodes sp. 2 & 1 \\
\hline Sphecodes sp. 4 & 1 \\
\hline Stelis subemarginata & 1 \\
\hline
\end{tabular}

Appendix 2. Continued.

Plant family / Flower binomial / Bee binomial $n$

Arnica cordifolia (10 spp.)

Agapostemon femoratus

Andrena sp. 5

Bombus bifarius

Bombus mixtus

Bombus occidentalis

Halictus farinosus

Osmia juxta

Osmia sculleni

Osmia subaustralis

Osmia tristella

Arnica fulgens var. sororia (7 spp.)

Andrena evoluta

Bombus bifarius

Hoplitis albifrons

Hylaeus basalis

Osmia californica

Osmia coloradensis

Osmia montana montana

Cirsium hookerianum (1 sp.)

Bombus insularis

Cirsium vulgare (4 spp.)

Bombus insularis

Lasioglossum tenax

Megachile montivaga

Osmia coloradensis

Crepis atrabarba (3 spp.)

Andrena evoluta

Hoplitis fulgida

Osmia montana

Erigeron acris var. debilis (3 spp.)

Anthidium mormonum

Nomada (Nomada) sp. 4

Osmia odontogaster

Erigeron corymbosus (2 spp.)

Osmia trevoris

Stelis subemarginata

Erigeron speciosus var. speciosus (42 spp.)

Agapostemon femoratus

Andrena scutellinitens

Ashmeadiella cubiceps

Bombus bifarius

Bombus centralis

Bombus flavifrons

Bombus insularis

Bombus melanopygus

Bombus mixtus

Bombus occidentalis

Bombus rufocinctus

Bombus sp.

Coelioxys moesta

Colletes fulgidus

Dianthidium heterulkei

Halictus farinosus

Halictus rubicundus

Heriades cressoni

Hoplitis albifrons

Hylaeus aff. coloradensis sp. 1

Hylaeus aff. coloradensis sp. 2

Lasioglossum (Dialictus) sp.

Lasioglossum sedi

Lasioglossum (Evylaeus) sp. 2 
ApPENDIX 2. Continued.

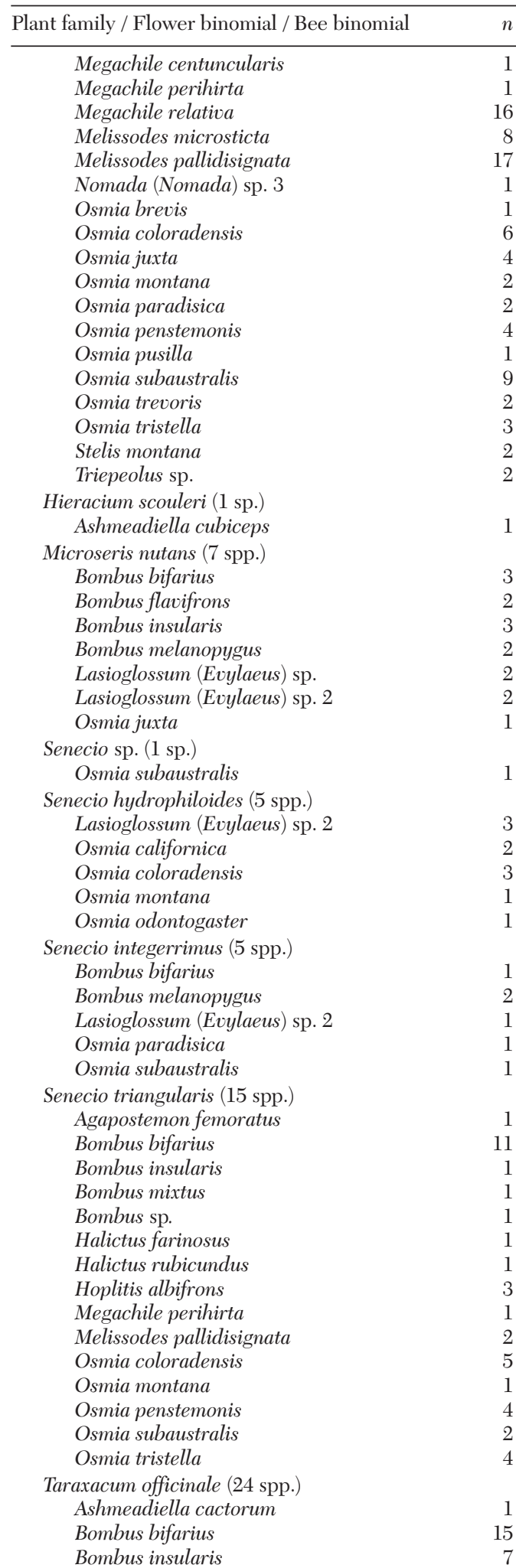

APPEndix 2. Continued.

\begin{tabular}{lr}
\hline Plant family / Flower binomial / Bee binomial & $n$ \\
\hline Bombus melanopygus & 3 \\
Bombus mixtus & 2 \\
Bombus sp. & 2 \\
Hoplitis albifrons & 1 \\
Hoplitis fulgida & 5 \\
Hylaeus annulatus & 1 \\
Hylaeus modestus & 2 \\
Lasioglossum (Evylaeus) sp. 2 & 11 \\
Lasioglossum marinense & 3 \\
Lasioglossum ruidosense & 1 \\
Lasioglossum sandhousiellum & 1 \\
Megachile perihirta & 2 \\
Megachile relativa & 2 \\
Osmia albolateralis & 2 \\
Osmia coloradensis & 19 \\
Osmia juxta & 6 \\
Osmia montana & 2 \\
Osmia penstemonis & 1 \\
Osmia pusilla & 4 \\
Osmia subaustralis & 1 \\
Osmia tristella & 13
\end{tabular}

BORAGINACEAE

Myosotis laxa (6 spp.)

Andrena rufosignata

Bombus appositus

Bombus melanopygus

Hoplitis fulgida

Osmia albolateralis

Osmia pusilla

BRASSICACEAE

Sisymbrium altissimum (7 spp.)

Agapostemon virescens

Bombus bifarius

Halictus rubicundus

Lasioglossum sisymbrii

Lasioglossum (Evylaeus) sp. 2

Megachile fidelis

Melissodes pallidisignata

Smelowskia calycina (5 spp.)

Andrena ribblei

Bombus fernaldae

Bombus insularis

Lasioglossum (Evylaeus) sp. 2

Megachile relativa

Campanulaceae

Campanula rotundifolia (5 spp.)

Halictus rubicundus

Lasioglossum sedi

Megachile gemula

Megachile melanophaea

CAPRIFOlicaeaE

Lonicera involucrata (1 sp.)

Bombus mixtus

Symphoricarpos albus (2 spp.)

Bombus bifarius

Bombus flavifrons

Caryophyllaceae

Arenaria capillaris (1 sp.)

Bombus melanopygus
3
3
2
2
1
5
1
2
1
3
1
1
2
2
2
9
6
2
1
4
1
13

3
1
1
6
1
1
1 5

1

1

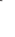

3

6

1 
APPENDIX 2. Continued.

\begin{tabular}{ll}
\hline Plant family / Flower binomial / Bee binomial & $n$ \\
\hline CRASSULACEAE & \\
Sedum lanceolatum (11 spp.) & 1 \\
Anthidium tenuiflorae & 1 \\
Bombus insularis & 1 \\
Chelostoma minutum & 2 \\
Colletes nigrifrons & 1 \\
Halictus rubicundus & 1 \\
Hylaeus aff. coloradensis sp.1 & 1 \\
Lasioglossum sedi & 1 \\
Lasioglossum (Evylaeus) sp. 2 & 1 \\
Osmia paradisica & \\
Osmia sp. 1 & 1 \\
Stelis subcaerulea & \\
ERICACEAE & 3 \\
Ledum glandulosum (1 sp.) & 4 \\
Andrena ceanothifloris & 1 \\
Phyllodoce empetriformis (3 spp.) & \\
Andrena rufosignata & \\
Bombus mixtus & \\
Lasioglossum (Evylaeus) sp. 2 &
\end{tabular}

FABACEAE

Astragalus miser var. miser (2 spp.)

Osmia albolateralis

Osmia longula

Astragalus miser var. serotinus (3 spp.)

Bombus bifarius

Bombus flavifrons

Bombus mixtus

Lupinus sericeus (10 spp.)

Andrena vicinoides

Bombus bifarius

Bombus centralis

Halictus rubicundus

Lasioglossum anhypops

Lasioglossum (Evylaeus) sp. 2

Megachile perihirta

Osmia californica

Osmia pusilla

Stelis montana

Lupinus sp. (8 spp.)

Bombus bifarius

Bombus mixtus

Bombus vandykei

Hoplitis albifrons

Lasioglossum (Evylaeus) sp.

Megachile gemula

Osmia paradisica

Osmia tristella

Melilotus alba (2 spp.)

Bombus bifarius

Bombus insularis

Oxytropis campestris var. cusickii (1 sp.)

Osmia tanneri

Trifolium pratense (5 spp.)

Bombus bifarius

Halictus rubicundus

Hoplitis albifrons

Osmia odontogaster

Osmia tristella

Trifolium repens (14 spp.)

Bombus bifarius
Appendix 2. Continued

\begin{tabular}{ll}
\hline Plant family / Flower binomial / Bee binomial & $n$ \\
\hline Bombus californicus & 1 \\
Bombus flavifrons & 2 \\
Bombus melanopygus & 1 \\
Hoplitis albifrons & 1 \\
Hylaeus annulatus & 1 \\
Megachile melanophaea & 1 \\
Osmia atrocyanea & 1 \\
Osmia exigua & 1 \\
Osmia juxta & 1 \\
Osmia odontogaster & 4 \\
Osmia penstemonis & 1 \\
Osmia pusilla & 6 \\
\end{tabular}

Geraniaceae

Geranium viscosissimum var. viscosissimum (2 spp.)

Bombus bifarius

Hylaeus annulatus

HYDROPHYLLACEAE

Phacelia leptosepala (24 spp.)

Anthidium mormonum

Anthidium tenuiflorae $\quad 2$

Ashmeadiella cactorum 1

Atoposmia copelandica 1

Bombus bifarius $\quad 18$

Bombus centralis $\quad 10$

Bombus fervidus 1

Bombus flavifrons $\quad 8$

Bombus melanopygus 1

Bombus sitkensis

Bombus vandykei

Colletes consors

Dufourea trochantera

Hoplitis albifrons

Hoplitis fulgida

Hylaeus aff. coloradensis sp. 1

Hylaeus annulatus

Hylaeus basalis

Lasioglossum (Evylaeus) sp.

Megachile gemula 1

Osmia juxta 2

Osmia pust

Osmia tristella

LILIACEAE

Calochortus lyallii (1 sp.) Andrena evoluta

ONAGRACEAE

Epilobium angustifolium (3 spp.)

Bombus bifarius

Lasioglossum (Evylaeus) sp. 2

Megachile relativa

Gayophytum diffusum ssp. parviflorum (3 spp.)

Lasioglossum (Evylaeus) sp. 2

Osmia penstemonis

Osmia tristella

Polemoniaceae

Gilia aggregata (1 sp.)

Lasioglossum sandhousiellum

Polemonium pulcherrimum (10 spp.)

Andrena ribblei

Bombus bifarius 
APPENDIX 2. Continued.

\begin{tabular}{ll}
\hline Plant family / Flower binomial / Bee binomial & $n$ \\
\hline Hoplitis fulgida & 4 \\
Osmia albolateralis & 1 \\
Osmia coloradensis & 2 \\
Osmia montana & 1 \\
Osmia paradisica & 1 \\
Osmia pusilla & 2 \\
Osmia tanneri & 1 \\
Osmia tristella & 6 \\
RANUNCULACEAE & \\
Delphinium nuttallianum (2 spp.) & 3 \\
Bombus flavifrons & 2 \\
Bombus mixtus &
\end{tabular}

RosACEAE

Dryas octopetala var. hookeriana (1 sp.) Osmia tanneri

Fragaria virginiana var. platypetala (4 spp.)

Osmia penstemonis

Osmia pusilla

Osmia subaustralis

Osmia tristella

Potentilla gracilis (23 spp.)

Andrena quintiliformis

Andrena ribblei

Andrena miranda

Andrena topazana

Andrena vicinoides

Bombus bifarius

Colletes nigrifrons

Halictus tripartitus

Hoplitis albifrons

Hoplitis fulgida

Hylaeus annulatus

Hylaeus modestus

Lasioglossum athabascense

Lasioglossum (Evylaeus) sp. 1

Lasioglossum (Evylaeus) sp. 2

Lasioglossum punctatoventre

Osmia marginipennis

Osmia montana

Osmia odontogaster

Osmia paradisica

Osmia pusilla

Osmia tristella

Sphecodes sp. 5

Rosa nutkana var. nutkana (12 spp.)

Andrena nivalis

Andrena salicifloris

Andrena topazana

Anthophora ursina

Bombus centralis

Bombus mixtus

Hoplitis albifrons

Hylaeus annulatus

Hylaeus basalis

Lasioglossum sedi

Lasioglossum (Evylaeus) sp. 2

Rubus parviflorus var. parviflorus (3 $\mathrm{spp}$.)

Andrena miranda

Bombus bifarius

Bombus mixtus
APPEndix 2. Continued.

\begin{tabular}{cc}
\hline Plant family / Flower binomial / Bee binomial & $n$ \\
\hline Rubus sp. (2 spp.) & 1 \\
Bombus melanopygus & 2
\end{tabular}

SAXIFRAGACEAE

Parnassia fimbriata (2 spp.)

Colletes nigrifrons

Lasioglossum sedi

SCrophulariaceae

Castilleja miniata (4 spp.)

Bombus fervidus

Bombus flavifrons

Bombus melanopygus

Osmia tristella

Orthocarpus tenuifolius (3 spp.)

Bombus appositus

Bombus bifarius

Bombus centralis

Pedicularis bracteosa var. latifolia (2 spp.) Andrena rufosignata

Bombus mixtus

Penstemon confertus (15 spp.)

Bombus appositus

Bombus bifarius

Bombus centralis

Bombus flavifrons

Bombus insularis

Bombus melanopygus

Bombus mixtus

Hoplitis albifrons

Hylaeus modestus

Osmia albolateralis

Osmia atrocyanea

Osmia brevis

Osmia juxta

Osmia pusilla

Osmia tristella

Penstemon davidsonii var. davidsonii (1 sp.) Lasioglossum sedi

Penstemon washingtonensis (22 spp.)

Agapostemon femoratus

Anthophora urbana

Bombus appositus 1

Bombus bifarius 12

Bombus californicus

Bombus centralis 1

Bombus fervidus

Bombus flavifrons

Bombus insularis $\quad 4$

Bombus mixtus 1

Bombus morrisoni 1

Colletes fulgidus 1

Colletes nigrifrons

Hylaeus aff. coloradensis sp. 1

Lasioglossum (Evylaeus) sp. 2

Megachile melanophaea

Osmia brevis $\quad 4$

Osmia longula 1

Osmia paradisica $\quad 30$

Osmia penstemonis $\quad 1$

Osmia sp. 1

Osmia tanneri 1 